\title{
Les produits utilisables pour le nettoyage et la désinfection du matériel endoscopique
}

\section{Introduction}

La Société Européenne d'Endoscopie Digestive (ESGE) et la Société Européenne des infirmières (ESGENA) constituent depuis de nombreuses années, un groupe de travail regroupant médecins, infirmières et industriels se rencontrant régulièrement pour faire le point sur les améliorations à apporter aux techniques de nettoyage et de désinfection.

De par sa composition hétérogène, ce groupe de travail représente un véritable creuset d'informations ; en effet, les industriels apportent des connaissances différentes et complémentaires sur le matériel et la compatibilité avec le matériel endoscopique. Il s'agit d'un lieu de dialogues tout à fait exceptionnel en Europe. Les contradictions, les discussions scientifiques permettent aux médecins et aux infirmières d'apporter leur vécu de terrain et la composition du groupe nous autorise également à connaître les difficultés liées à telle ou telle marque et à tel ou tel produit, ce qui n'est pas possible lorsque l'on discute isolément avec chacun des industriels intervenants.

Ce document est une mise au point européenne, basée sur des critères scientifiques reconnus au niveau international. Le document final a été revu par l'ensemble des participants et il prend en compte également les nécessités économiques et le choix qu'il faut réserver aux différents pays en fonction du contexte médico-économique. La dernière publication dans la livraison de mai de Gastrointestinal
Endoscopy montre que parfois, la France a une attitude jusqu'au boutiste, liée aux traumatismes que les responsables de la Direction Générale de la Santé ont vécu à travers le scandale du sang contaminé. Vingt ans après, il faut revenir à des bases scientifiques et internationales et ne pas impliquer à tort l'endoscopie digestive dans un risque nosocomial excessif. En France, dès 1982, la SFED et le GIFE ont œuvré pour améliorer les règles de nettoyage et de désinfection du matériel endoscopique. Nous ne retrouvons pas toujours dans nos rapports avec les autorités de tutelle, une reconnaissance de nos efforts.

Enfin, il faut être conscient que les produits arrivés récemment sur le marché, c'est-à-dire les acides peracétiques entraînent soit des avaries importantes sur le matériel endoscopique, soit dans tous les cas, une usure prématurée. Au moment où notre système de santé présente un déficit structurel important, est-il utile d'augmenter la charge financière des services d'endoscopie pour un bénéfice qui reste virtuel en ce qui concerne le variant de la maladie de CreutzfeldtJacob puisque à ce jour, il n'y a toujours que 120 cas en Angleterre, 6 cas en France et 1 cas en Italie.

Il est indispensable que la DGS, la DHOS et l'AFSSAPS prennent en compte enfin l'importance en terme de bénéfice clinique qu'apporte l'endoscopie digestive aux patients.

Jean-François REY Président élu de l'ESGE

\section{Technical note on Cleaning and Disinfection}

\section{ESGE Guidelines Committee}

\section{FOREWORD}

The ESGE together with ESGENA and the biomedical industry met under the auspices of the ESGE Guidelines Committee to discuss and propose this technical note on cleaning and disinfection in order to clarify this technically difficult topic for the daily user.

\section{INTRODUCTION}

It is all important to emphasize that the most critical step in cleaning/disinfection is cleaning. It is impossible to disinfect or even terminally sterilize an inadequately cleaned instrument. Protein debris can become fixed and induce biofilm on the biopsy channel of the scope, if the manual cleaning, brushing, and rinsing step are not properly carried out. In short, all disinfection processes, whether done manually or by washer-disinfector, should be performed only after proper cleaning.

Furthermore, due to the fear of prion particle contamination, some guidelines recommend a double brushing procedure in order to remove all protein particles more efficiently. We should underline that our society has published numerous guidelines during the past ten years and that, as a result, the safety of digestive endoscopy has never before been at such a high level. The importance of endoscopy, as a diagnostic and therapeutic tool, is far behind the isolated report of nosocomial risk linked to the endoscopic procedure, as most of the cases can be considered malpractice. The onset of variant Creutzfeldt Jakob Disease (vCJD) has raised some concern about the safety of digestive endoscopy. However, now that we understand that the number of cases in France and 